\title{
第1日G会場
}

一般演題：外傷性脳損傷・ほか

座長 先 崎

章

I-G1-1 1 力月の意識消失を伴う外傷性脳挫傷受傷後 30 年経過した潜在的高次脳機能障害の一例について

国立保健医療科学院

医療法人社団松井病院

橘 とも子

慶應義熟大学医学部精神神経科学教室

橘秀昭

加藤元一郎

〔症例〕 47 歳女性医師。16 歳時, 暴走車激突により 1 力月 間の意識消失を伴う脳挫傷, 頭蓋底骨折, 全身多発外傷。神 経主症状は視神経管骨折による右眼失明, 左顔面神経麻痻, 左耳感音難聴, 上肢の右側感覚麻疩 - 左側運動麻疩。受傷半 年後の脳波所見は「左側の $\alpha$ 波抑制, 徐波が前部は右に後部 は左に多い」。受傷 3 年後大学医学部入学。生来成績優秀素 行に問題なく中学卒業時の学業成績は 9 教科オール 5 , 行動 評価はオール A。記憶力・集中力の著しい低下を学習困難要 因と自覚したが反復・外的代償・内的視覚イメージ等により 自主的に補完し 6 年間で医学部を卒業，同年医師国家試験合 格。この間焦燥感・いらだちを自覚, 他覚的には時に衝動的 行動・たどたどしい話し方あるも医療ケア介入無し。下肢再 手術後内科医となり就業中に死に対する恐怖感增強によるう つ状態発症。以降時にパニック発作等感情のコントロール不 安定等のエピソードはあるも社会的活動を継続。現在の病態 について精神神経科学的高診を目的に受診。

【検查所見】頭部 MRI：左後頭葉皮質の萎縮像, 脳波：正 常。

〔神経心理学的所見〕 WAIS-3 ; 言語性 IQ 130, 動作性 IQ 113, WMS-R ; 言語性記憶 101（論理的記憶 $21 / 50$, 言語性 対連合 $24 / 24$ ), 視覚性記憶 117 , 一般的記憶 107 , 遅延再生 111 (論理 20/50, 視覚対 6/6, 言語対 $8 / 8$, 視覚再生 40/41), 注意/集中力 138 , 論理的記憶: 即時 $44 \cdot$ - 遅延 61 , 視覚性再 生 : 即時 $82 \cdot$ 遅延 87 。

〔考察とまとめ〕本例では認知機能の回復訓練を医学教育 自体が代替したと考えられる。動作性 IQ の有意な低下は視 覚情報の処理速度や視機能障害による全体把握能力低下の関 与が示唆された。本症例は本人の専門的知的能力により自助 ケア可能な潜在的高次脳機能障害者であり現状で精神心理学 的介入の必要性はないが, 論理的記憶に遅延再生で得点改善 はあるものの直後再生に顕著な相対的低下がみられ, 認知症 の発症有無等について今後慎重に経過観察が必要と思われ る。 


\section{I-G1-4 頭部外傷により顕著な作話を呈した一症例}

石川病院リハビリテーション室 三角 幸子 徳澤 勝也 馬瀬 麗子 〔はじめに〕今回，頭部外傷により重度の作話を呈する症 例を経験した。入院経過における作話や特異的な発話症状に ついて考察し，報告する。

〔症例〕59歳，男性。医学的診断名：脳挫傷（びまん性軸 索損傷）H20.5.2 発症。画像所見：両側前頭葉から頭頂葉の 皮質・白質及び脳梁に多発性小出血, 大脳半球裂にクモ膜下 出血，軸索損傷を認める。

〔神経心理学的所見〕前向性健忘・逆向性健忘，見当識障 害 (時・場所 - 地誌的), 注意障害, 構成障害, 意欲低下, 発動性低下を認める。知的機能：MMSE 11/30 点, コース 立方体 IQ 55。WAIS-R：VIQ 79，PIQ 64，FIQ 71。記憶検 查：三宅式記銘力検查で有関係対語 2-2-2, 無関係対語 1-0 -0 。

〔発話サンプル〕会話場面：「ビニの中から毛虫が出てき て，祈䘠師とはもっと体を動かさなあかんね。」(空想)。「今 から車運転して帰らんとあかんのです。」(追想)。年齢は？ $\rightarrow\lceil 78.9$ 歳。年寄りは 1 時間ほっといたらいい。」(応答)。

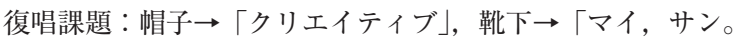
私が罪に使うのは靴下です」など。 
〔経過〕入院当初, 空想作話・追想作話・応答作話が頻発 し, 自発性・誘発性共に出現した。発話内容に首尾一貫性は なく特異的。でまかせ反応が頻発。入院 2 力月頃より空想作 話が減少し, 追想・応答作話が目立つものの, 次第に会話が 成立する場面が増加した。

〔考察〕作話出現については, 前頭葉眼窩部を含む前脳基 底部が関与したものと考える。特異的な発話や空想作話には, 思考過程で矛盾が起きた時に解決する機能の低下や滅裂思考 が起因したものと考えられた。特異的発話の出現には, 思考 障害から無関係観念・表象が存在し, 発話抑制困難状態で, さらに表出された発話が自己監視機構の障害により修正困難 であることが機序として考えられた。

\section{I-G1-5 Mild traumatic brain injury が疑われる一例}

東京福祉大学社会福祉学部

埼玉県総合リハビリテーションセンター 埼玉県総合リハビリテーションセンター 井之頭病院

昭和大学医学部精神医学教室

慶應義塾大学医学部精神神経科学教室

加藤元一郎 鹿島 晴雄

〔はじめに〕脳外傷後の意識消失の持続が 30 分以下で，か つ GCS13 以上の軽度な場合 Mild traumatic brain injury（軽度 脳損傷, 以下 MTBI と略）と呼ばれ，しばしば注意・集中力 の低下, 頭痛・倦怠, うつ・不安といったいわゆる脳震盪後 症状が持続する。今回, 脳外傷後 4 力月時点でうつと記憶障 害, 遂行機能障害, 易疲労性がみられ, うつが改善した後も, これらの症状が持続し, MTBI と診断しうる症例を経験した ので若干の考察を交えて報告する。

〔症例〕50歳代男性, 会社経営者。自動車運転中に追突さ れ, 救急隊が到着した際には, ほぼ意識消失から回復してい る状態。事故後数日で復職したが，うつ，不眠あり。また， 車の車庫入れの際に，注意を適度に配分できず車体をぶつけ てしまうミスを繰り返したため受傷 4 カ月時に初診に至っ た。MRI（含 $\mathrm{T} 2 *$ ) にて異常を認めず。

〔検查所見】 RBMT 17/24, TMT-A 129s B 103s, BADS 標 準化得点 90 , 厚生労働省編一般職業適性検查では 6 項目で $\mathrm{E}$, SDS 48 点。

〔治療と経過〕うつや不眠は trazodone で改善。臨床上の注 意力低下や遂行機能障害はうつ改善後も持続し, 職業適性検 查での改善なし。注意障害, 易疲労性に対しては随時休息を とる, 遂行機能障害に対して行動の細分化とサブゴールの設 定を行うことで, 仕事は事故前の 50 \% 程度の量・質で行え るようになり, 受傷後 2 年半経過する。自賠責保険では脳外 傷の後遺症とは認定されなかったが, そのために症状や訴え が変化することはなかった。

〔考察〕うつ改善後も神経心理学的障害が持続したため, MTBI を疑った。本人は, 保険上後遺症との認定がされなか ったことにこだわりはなく, また症状が一貫しており, 職務 (会社経営) や社会的立場になんのメリットもなく, 詐病や
ヒステリーは考えにくい。

\section{I-G1-6 脳外傷者の神経心理学的検査と生活上の問題の関 連認知/行動障害尺度, WAIS-III, BADS の統計的 検討}

神奈川リハビリテーション病院心理科 佐野 玲子 大橋 正洋 斉藤 敏子 下田 正代 坂本 久恵 山本真裕美 長尾 初瀬 殿村暁林惠子

吉備国際大学社会福祉学部 久保 義郎

〔はじめに〕高次脑機能障害には様々な側面があり, 日常 生活や社会生活に大きな影響を与える。神経心理学的検査は 机上の検查によって, 高次脳機能の問題点を探り, リハビリ テーションや社会適応に役立つ情報を得るよう開発されてき た。しかし, 評価結果は家族が日常生活で感じる問題を必ず しも反映しないとの見方もある。今回，家族により不適応行 動を因子別に評定する検查（TBI-31）を用い神経心理学的 検査との関連を検討した。

〔対象〕 2006 年 10 月～ 2009 年 3 月にWAIS-III, BADS, 脳外傷者の認知-行動障害尺度（TBI-31）を実施した脳外傷 患者のうち, WAIS-IIIの FIQ が 80 以上でデー夕の久損率が $20 \%$ 以下の 32 名（男： 27 名, 女：5名, 平均年齢： 36.47 歳, SD 12.91 歳)。

〔方法〕WAIS-正は各群指数と下位検査の評価点, BADS は下位検查のプロフィール得点, TBI- 31 は各因子の $Z$ 得点 を用い, TBI-31 とWAIS-III, BADS との相関係数を算出し た。

〔結果〕 TBI-31 と WAIS-IIIでは因子 2(易疲労性/意欲の 低下）と語音整列，因子 5 （情動コントロールの低下）と知 識で中程度の逆相関, TBI-31 と BADS では因子 7 (課題遂 行力の低下）と動物園地図で中程度の逆相関がみられた。 TBI-31の第 1 因子（健忘)，第 3 因子（対人場面での状況判 断力の低下), 第 4 因子 (固執性), 第 6 因子 (現実検討力の 低下）とWAIS-III，BADS では明らかな相関はみられなかっ た。

[考察]日常生活上の問題は神経心理学的検査の量的指標 では説明できないと言われる。しかし，今回の検討では，脳 外傷者の生活上の問題を評定する TBI-31において, 神経心 理学的検查の結果と相関がみられる因子が認められた。神経 心理検查から生活上の問題を予測することは難しいが，一つ の指標となりうる可能性が示唆された。 